\title{
PREVALENCE AND CHARACTERISTICS OF SHIGA TOXIN-PRODUCING ESCHERICHIA COLI (STEC) STRAINS IN GROUND BEEF IN SÃO PAULO, BRAZIL
}

\author{
Alzira Maria Morato Bergamini ${ }^{1 *}$; Marise Simões²; Kinue Irino³; Tânia Aparecida Tardelli Gomes; \\ Beatriz Ernestina Cabilio Guth ${ }^{4}$
}

\begin{abstract}
${ }^{1}$ Setor de Microbiologia de Alimentos, Instituto Adolfo Lutz, Laboratório I de Ribeirão Preto, Ribeirão Preto, SP, Brasil; ${ }^{2}$ Setor de Microbiologia de Alimentos, Instituto Adolfo Lutz, Laboratório I de Campinas, Campinas, SP, Brasil; ${ }^{3}$ Setor de Enterobactérias, Instituto Adolfo Lutz, São Paulo, SP, Brasil; ${ }^{4}$ Departamento de Microbiologia, Imunologia e Parasitologia, Universidade Federal de São Paulo, São Paulo, SP, Brasil
\end{abstract}

Submitted: December 21, 2006; Returned to authors for corrections: April 13, 2007; Approved: July 18, 2007.

\begin{abstract}
This study aims to assess the prevalence of Shiga toxin-producing Escherichia coli (STEC) in ground beef collected in two cities located in the State of São Paulo, Brazil. A total of 250 samples of raw ground beef were collected in local grocery stores during the period of March to December 2002 in the cities of Ribeirão Preto (114 samples) and Campinas (136 samples), São Paulo State, Brazil. The samples were processed according to standard methods. The resulting 591 E.coli colonies were screened for STEC by hybridization assays using the specific DNA probes, stx 1, st $x_{2}$ and eae. Further characterization of STEC isolates included the search for the $e h x A$ sequence, detection of enterohemolysin and expression of Shiga toxin using the Vero cell assay. STEC isolates belonging to serotypes O93:H19, ONT:HNT, ONT:H7, and O174:HNT we recovered from four samples (3.5\%) collected in Ribeirão Preto. All samples from Campinas were negative for STEC. Three of the strains carried $s t x_{2}$ and $e h x A$ sequences while one harbored stx $x_{1}$, st $x_{2}$ and $e h x A$ sequences. Considering that among foods of animal origin, ground beef is an important vehicle for STEC transmission, these data emphasize the need of a closer surveillance of these microorganisms. They can survive in unfavorable conditions specially when the products are refrigerated or frozen for long periods of time and can be the cause of outbreaks affecting a great number of consumers.
\end{abstract}

Key words: Escherichia coli, Shiga toxin, STEC, Serotypes, Ground beef

\section{INTRODUCTION}

Shiga toxin-producing E. coli strains are associated with a broad spectrum of human illnesses throughout the world, ranging from mild diarrhea to hemorrhagic colitis (HC), hemolytic uremic syndrome (HUS) and thrombotic thrombocytopenic purpura (TTP) $(10,16)$. Currently, hundreds of distinct serotypes are recognized as STEC and associated with human diseases (25). Serotypes such as O157:H7, O111:H8, O26:H11, O103:H2, referred to as enterohemorrhagic (EHEC) and bearing the eae gene and the EHEC plasmid, are more frequently related to severe human illnesses $(16,17)$.
Domestic and wild animals are reported as sources of these microorganisms; but cattle, sheep and goat are considered as the main reservoir (2). Foods of animal origin, especially ground beef, probably contaminated during the grinding process, have been identified as the main vehicles for transmission of E.coli O157:H7 and other non-O157 STEC strains to humans. However, foods like raw milk, fruits and vegetables, as well as cross contamination due to inadequate food manipulation, and personto-person transmission have already been associated with human disease (10).

The major STEC virulence factors are considered to be the Shiga toxins, Stx 1 and Stx2, which may be produced together or

*Corresponding Author. Mailing address: Rua Minas, 877 Campos Eliseos 14085-410 Ribeirão Preto, SP - Brasil. Tel.: (16) 3625-5046 ou (16) 3635 7994. E-mail: ammbergamini@ial.sp.gov.br ou alzirabergamini@bol.com.br 
not by the STEC isolates. Additional factors such as intimin and enterohemolysin are harbored by some serotypes, and a growing number of putative virulence factors are also being reported (22).

In many countries, $\mathrm{O} 157: \mathrm{H} 7$ is the most prevalent serotype associated to sporadic cases or large outbreaks of hemorrhagic colitis and HUS. However, many distinct non-O157 STEC serotypes have also been increasingly reported as the causative agents of human disease (16).

Although some studies in Brazil reported the occurrence of STEC in different animal reservoirs $(12,14,24)$, data concerning isolation of these microorganisms from food of animal origin is scarce $(3,7,19)$.

Thus, the aim of this study was to evaluate the prevalence of STEC in ground beef collected in two cities of the State of São Paulo, Brazil.

\section{MATERIALS AND METHODS}

\section{Ground beef samples}

A total of 250 samples of raw ground beef were collected from local grocery stores during the period of March to December 2002, in the cities of Ribeirão Preto (114 samples) and Campinas (136 samples), both located in the State of São Paulo, Brazil.

\section{Preparation of samples}

Ground beef samples were processed according to the Compendium of Methods for the Microbiological Examination of Foods (13) with some modifications. Briefly, 25g of each sample was homogenized in $225 \mathrm{~mL}$ of Buffered Peptone Water (BPW, $1 \%$ ), incubated for 6 and 24 hours at $35^{\circ} \mathrm{C}$, streaked on MacConkey Sorbitol Agar and further incubated for $18-24$ hours at $35^{\circ} \mathrm{C}$.

\section{Isolation of $E$.coli}

Five to ten sorbitol positive and negative colonies from each sample were inoculated into the presumptive diagnostic medium IAL (18) and incubated overnight at $35^{\circ} \mathrm{C}$. The IAL medium is tubed in two layers and distinguishes Enterobacteriaceae based on the following biochemical properties: indole, hydrogen sulfide and urease production, acid from glucose and sucrose, gas from glucose, presence of Ltryptophane deaminase and lysine decarboxylase.

\section{Screening for STEC}

A total of 591 E.coli isolates were screened for STEC by colony hybridization assays with specific DNA probes for $s t x_{1}$ and $s t x_{2}$ (23). All sorbitol negative E.coli isolates were previously submitted to the slide agglutination test with $\mathrm{O} 157$ antiserum.

\section{Search for additional virulence factors}

The intimin (eae) and the plasmid-encoding enterohemolysin (ehxA) genes were detected by PCR assays according to Gannon et al. (8) and Schmidt et al. (20), respectively.

\section{Detection of Shiga toxin (Stx) and enterohemolysin}

Sterile supernatants, prepared from STEC isolates, were inoculated into Vero cells monolayers and the Stx cytotoxic effect observed after 24-48 hours incubation periods (9). Enterohemolysin production was investigated according to Beutin et al. (1) using blood agar plates containing $5 \%$ of washed sheep blood cells and supplemented with $10 \mathrm{mM} \mathrm{CaCl}$. The plates were incubated at $37^{\circ} \mathrm{C}$ and the hemolytic activity was observed after $3 \mathrm{~h}$ and 18-24 $\mathrm{h}$ incubation periods. STEC strains showing hemolytic activity after 18-24 hours incubation were identified as enterohemolytic.

\section{Serotyping}

$\mathrm{OH}$ serotyping was done following standard methods (5) and using currently available $\mathrm{O}$ (O1-O181) and $\mathrm{H}$ (H1- H56) antisera prepared at Instituto Adolfo Lutz, São Paulo, using reference strains from E. coli and Klebsiella International Reference Centre, Copenhagen, Denmark.

\section{RESULTS}

\section{STEC isolation}

Among the 114 samples of ground beef collected in Ribeirão Preto, $4(3.5 \%)$ were positive for STEC while all samples collected in Campinas were negative.

\section{Serotypes and genetic profiles}

The four STEC strains belonged to serotypes O93:H19; ONT:HNT; ONT:H7; and O174:HNT. Sequences st $x_{2}$ and $e h x A$ were found in three of the strains and one carried $s t x_{1}, s t x_{2}$ and $e h x A$ sequences. None carried eae. Strain characteristics are summarized in the Table 1.

Table 1. Characteristics of Shiga toxin-producing E. coli isolated from ground beef in Ribeirão Preto, SP.

\begin{tabular}{lcccc}
\hline Serotypes & O93:H19 & ONT:HNT & ONT:H7 & O174:HNT \\
\hline Genetic profile* & stx $x_{2}$ ehxA & stx $x_{1}$ & st $x_{2}$ ehxA & stx \\
ehxA & st $x_{2}$ eh $x A$ \\
Cytotoxic activity & + & + & + & + \\
Enterohemolysin & + & + & + & + \\
\hline
\end{tabular}

*none of the strains carried the eae sequence.

\section{DISCUSSION}

Outbreaks and sporadic cases of infections due to STEC strains are mainly associated with the consumption of contaminated food of animal origin, especially ground beef(15). STEC isolation in ground beef and other foods were described in several countries. Hussein and Bollinger (11), analyzing data from 
STEC in ground beef

30 surveys on packaged and unpackaged meat from supermarkets, showed that STEC prevalence ranged from 0.01 to $54.2 \%$.

In the present study $3.5 \%$ of the ground beef samples collected in the region of Ribeirão Preto were contaminated with STEC. This is in agreement with the low frequency $(1.75 \%)$ of non-O157 STEC strains found in minced beef and pork samples in Switzerland as reported by Fantelli and Stephan (6). However, our data is in contrast to the high STEC rate found in refrigerated or frozen ground beef and frozen hamburger patties analyzed in Rio de Janeiro, Brazil (3).

The four strains isolated from raw ground meat in Ribeirão Preto belonged to serotypes other than O157, which is in accordance to the study conducted in Brazil by Cerqueira et al. (3). Low frequency of Escherichia coli $\mathrm{O} 157$ in food samples has been previously reported by several authors $(4,6,9)$. In Brazil O157:H7 STEC strains were not detected in meat samples probably due to the methodology employed in the screening $(3,19)$.

Three of four STEC strains harboured the $s t x_{2}$ sequence and one carried both, $s t x_{1}$ and $s t x_{2}$. STEC strains exhibiting these profiles were expected since STEC isolates from Brazilian beef and dairy cattle, and from sheep were shown to carry $s t x_{2}$ or $s t x_{1}+s t x_{2}$ sequences $(12,14,24)$. Predominance of STEC strains carrying $s t x_{2}$ sequences in ground meat, very popular among Brazilian consumers, could become a serious risk to public health since strains carrying these sequences usually lead to extra intestinal complications like HUS $(10,17)$.

According to Sandhu et al. (21), presence of the eae gene in STEC strains is associated with some $\mathrm{O}$ groups such as $\mathrm{O} 26$, O103, O111, O157 among others. The absence of the eae gene in the four strains identified in this study probably is related to their O-groups. Fantelli and Stephan (6) also reported that all non-O157 STEC strains from minced meat were negative for the eae gene. Although eae carrying STEC strains are frequently associated with severe infections, outbreaks of HUS by eae negative STEC strains have already been reported (17).

The data emphasize the need of a strict surveillance of these microorganisms in food items, particularly in meat and other products of animal origin. STEC strains can survive in refrigerated or frozen food for long periods and thus easily contaminate consumers.

As food samples usually have low numbers of O157strains, enrichment methods such as immunomagnetic separations should be used to isolate these microorganisms. Economical limitations in the use of improved enrichment procedures and the lack of differential media for detection of all other non-O157 serotypes is still a drawback in STEC screening in developing countries.

Furthermore, although foodborne diseases are important issues to health authorities all over the world, they are underreported leading to a scarcity of data especially in developing countries.

\section{ACKNOWLEDGEMENTS}

This study was supported by grants from Fundação de Amparo à Pesquisa do Estado de São Paulo (FAPESP) № 01/ 07921-7 and 03/12193-6 awarded to B.E.C.G. and K.I., respectively.

\section{RESUMO}

\section{Prevalência e características de cepas de Escherichia coli produtoras de toxina Shiga (STEC) em carne bovina coletada em São Paulo, Brasil}

O objetivo deste estudo foi verificar a ocorrência de Escherichia coli produtora de toxina Shiga (STEC) em amostras de carne moída crua comercializadas em duas cidades do Estado de São Paulo, Brasil. Um total de 250 amostras de carne moída crua foi coletado de açougues locais durante o período de Março a Dezembro de 2002, nas cidades de Ribeirão Preto (114 amostras) e de Campinas (136 amostras), Estado de São Paulo, Brasil. As amostras foram processadas de acordo com os métodos de referência. Um total de 591 colônias de E.coli foi submetido à técnica de hibridização de colônias usando sondas específicas de DNA para a detecção das seqüências $s t x_{1}, s t x_{2}$ e eae. Caracterizações adicionais das cepas STEC incluíram a pesquisa da seqüência $e h x A$, a detecção da enterohemolisina e a pesquisa da expressão de toxina Shiga utilizando testes com células Vero. Em quatro amostras $(3,5 \%)$ coletadas em Ribeirão Preto, foram encontradas cepas STEC, mas todas aquelas da região de Campinas foram negativas. As cepas de STEC pertenciam aos sorotipos O93:H19, ONT:HNT, ONT:H7, e O174:HNT. Três cepas tinham o perfil stx $x_{2} e h x A$ e uma era portadora das sequiências $s t x_{1}, s t x_{2}$ e $e h x A$. Considerando que entre os alimentos de origem animal, a carne moída ainda representa um importante veículo de transmissão de STEC, estes dados alertam para a necessidade de uma vigilância da presença destes microrganismos capazes de sobreviver em condições desfavoráveis, especialmente quando os produtos são refrigerados ou congelados por longos períodos, podendo ser causas de importantes surtos afetando grande número de consumidores.

Palavras-chaves: Escherichia coli; toxina Shiga; STEC; Sorotipos; Carne moída

\section{REFERENCES}

1. Beutin, L.; Montenegro, M.A.; Orskov, I.; Orskov, F.; Prada, J.; Zimmerman, S.; Stephan, R. (1989). Close association of verotoxin (Shiga-like toxin) production with enterohemolysin production in strains of Escherichia coli. J. Clin. Microbiol., 27(11), 2559-2564.

2. Beutin, L.; Geier, D.; Steinruck, H; Zimmermann, S.; Scheutz, F. (1993). Prevalence and some properties of verotoxin (Shiga-like toxin)-producing Escherichia coli in seven different species of healthy domestic animals. J. Clin. Microbiol., 31(9), 2483-2488. 
3. Cerqueira, A.M.F.; Tibana, A.; Guth, B.E.C. (1997). High occurrence of Shiga-like-producing strains among diarrheagenic Escherichia coli isolated from raw beef products in Rio de Janeiro City, Brazil. $J$. Food Prot., 60(2), 177-180.

4. Conedera, G.; Dalvit, P.; Martini, M.; Galiero, G.; Gramaglia, M.; Goffredo, E.; Loffredo, G.; Morabito, S.; Ottaviani, D.; Paterlini, F.; Pezzotti, G.; Pisanu, M.; Semprini, P.; Caprioli, A. (2004). Verocytotoxin-producing Escherichia coli 0157 in minced beef and dairy products in Italy. Int. J. Food Microbiol., 96(1), 67-73.

5. Ewing, W.H. (1986). The genus Escherichia. In: Edwards \& Ewing's identification of Enterobacteriaceae. $4^{\text {th }}$ ed. Elsevier Science Publishing Co., Inc., New York, p.67-107.

6. Fantelli, K.; Stephan, R. (2001). Prevalence and characteristics of Shiga toxin-producing Escherichia coli and Listeria monocytogenes strains isolated from minced meat in Switzerland. Int. J. Food Microbiol., 70(1-2), 63-69.

7. Franco, B.D.G.M.; Gomes, T.A.T.; Jakabi, M.; Marques, L.R.M. (1991). Use of probes to detect virulence factor DNA sequences in Escherichia coli isolated from foods. Int. J. Food Microbiol., 12(4), 333-338.

8. Gannon, V.P.; Rashed, M.; King, R.K.; Thomas, E.J. (1993). Detection and characterization of the eae gene of Shiga-like toxin-producing Escherichia coli using polymerase chain reaction. J. Clin. Microbiol., 31(5), 1268-1274.

9. Gentry, M.K.; Dalrymple, J.M. (1980). Quantitative microtiter citotoxicity assay for Shigella toxin. J. Clin. Microbiol., 12(3), 361-366.

10. Griffin, P.; Tauxe, R.V. (1991). The epidemiology of infections caused by Escherichia coli O157:H7, other enterohemorrhagic Escherichia coli, and the associated hemolytic uremic syndrome. Epidemiol. Rev., 13, 60-98.

11. Hussein, H.S.; Bollinger, L.M. (2005). Prevalence of Shiga toxinproducing Escherichia coli in beef. Meat Sci., 71(4), 676-689.

12. Irino, K.; Kato, M.F.; Vaz, T.M.I.; Souza, M.A.C.; Cruz, A.S.; Gomes, T.A.T.; Vieira, M.; Guth, B.E.G. (2005). Serotypes and virulence markers of Shiga toxin-producing Escherichia coli (STEC) isolated from dairy cattle in São Paulo State, Brazil. Vet. Microbiol., 105(1), 29-36.

13. Kornacki, J.L.; Johnson, J.L. (2001). Enterobacteriacea, coliforms and Escherichia coli as quality and safety indicators. In: Downes, F.P.; Ito, K. (eds). Compendium of methods for the microbiological examination of foods. American Public Health Association (APHA), Washington, D.C., p.69-82.
14. Leomil, L.; Aidar-Ugrinovich, L.; Guth, B.E.C.; Irino, K.; Vettorato, M.P.; Onuma, D.L.; de Castro, A.F.P. (2003). Frequency of Shiga toxin-producing Escherichia coli (STEC) isolates among diarrheic and non-diarrheic calves in Brazil. Vet. Microbiol., 97(1-2), 103-109.

15. López, E.L.; Contrini, M.M.; Sanz, M.; Viñas, M.R.; Parma, A.; de Rosa, M.F.; Cleary, T.G. (1997). Perspectives on Shiga-like toxin infections in Argentina. J. Food Prot., 60(11), 1458-1462.

16. Nataro, J.P.; Kaper, J.B. (1998). Diarrheagenic Escherichia coli. Clin. Microbiol. Rev., 11(1), 142-201.

17. Paton, J.C.; Paton, A.W. (1998). Pathogenesis and diagnosis of Shiga toxin-producing Escherichia coli infections. Clin. Microbiol. Rev., 11(3), 450-479.

18. Pessôa, G.V.A.; Silva, E.A.M. (1974). Milieu pour l'identification présomptive rapide des entérobactéries, des Aeromonas et des vibrions. Ann. Microbiol., Paris, p.341-347.

19. Silveira, N.F.A.; Silva, N.; Contreras, C.; Miyagusku, L.; Baccin, M.L.F.; Koono, E.; Beraquet, N.J. (1999). Occurrence of Escherichia coli O157:H7 in hamburgers produced in Brazil. J. Food Prot., 62(11), 1333-1335.

20. Schmidt, H.; Beutin, L.; Karch, H. (1995). Molecular analysis of the plasmid-encoded hemolysin of Escherichia coli O157:H7 strain EDL 933. Infect. Immun., 63(3), 1055-1061.

21. Sandhu, K.S.; Clarke, R.C.; McFadden, K.; Brouwer, A.; Louie, M.; Wilson, J.; Lior, H.; Gyles, C.L. (1996). Prevalence of the eaeA gene in verotoxigenic Escherichia coli strains from dairy cattle in southwest Ontario. Epidemiol. Infect., 116(1), 1-7.

22. Toma, C.; Espinosa, E.M.; Song, T.; Miliwebsky, E.; Chinen, I.; Iyoda, S.; Iwanaga, M.; Rivas, M. (2004). Distribution of putative adhesins in different seropathotypes of Shiga toxin-producing Escherichia coli. J. Clin. Microbiol., 42(11), 4937-4946.

23. Vaz, T.M.I.; Irino, K.; Kato, M.A.M.F.; Dias, A.M.G.; Gomes, T.A.T.; Medeiros, M.I.C.; Rocha, M.M.M.; Guth. B.E.C. (2004). Virulence properties and characteristics of Shiga toxin- producing Escherichia coli in São Paulo, Brazil, from 1976 through 1999. J. Clin. Microbiol., 42(2), 903-905.

24. Vettorato, M.P.; Leomil, L.; Guth, B.E.C.; Irino, K.; Pestana de Castro, A.F. (2003). Properties of Shiga toxin-producing Escherichia coli (STEC) isolates from sheep in the State of São Paulo, Brazil. Vet. Microbiol., 95(1-2), 103-109.

25. Zweifel, C.; Schumacher, S.; Blanco, M.; Blanco, J.E.; Tasara, T.; Blanco, J.; Stephan, R. (2005). Phenotypic and genotypic characteristics of non-O157 Shiga toxin-producing Escherichia coli (STEC) from Swiss cattle. Vet. Microbiol., 105(1), 37-45. 